\title{
11. Best-practice whistleblowing legislation for the public sector: the key principles
}

\author{
A. J. Brown, Paul Latimer, John McMillan and Chris Wheeler
}

\section{Introduction}

In Australia, legislative frameworks have long been considered fundamental to encouraging and managing public interest disclosures. Since 1993, almost all Australian jurisdictions have put in place relevant legislation for the public sector, as shown in Table 11.1. In practice, the content of whistleblowing legislation has nevertheless been a vexed issue. Several jurisdictions, including New South Wales, Western Australia and Victoria, have conducted or are conducting major reviews of their legislation, at least partly in response to public doubts about its effectiveness. Bills for new or replacement legislation have been introduced in the Northern Territory and the Australian Capital Territory. At the Commonwealth level, where comprehensive legislation has long been recommended (Senate Select Committee on Public Interest Whistleblowing 1994; McMillan 1994), private member's bills were introduced, but lapsed, in 2001 and 2007. Most recently, the new Commonwealth Government has committed itself to 'provide best-practice legislation to encourage and protect public interest disclosure within government' (ALP 2007).

Table 11.1 Australian public sector whistleblowing legislation, in date order

\begin{tabular}{lll}
\hline No. & Act/bill & Jurisdiction \\
\hline 1 & Whistleblowers Protection Act 1993 & South Australia \\
2 & Whistleblowers Protection Act 1994 & Queensland \\
3 & Protected Disclosures Act 1994 & New South Wales \\
4 & Public Interest Disclosure Act 1994 & Australian Capital Territory \\
5 & Public Service Act 1999, section 16 & Commonwealth \\
6 & Whistleblowers Protection Act 2001 & Victoria \\
7 & Public Interest Disclosures Act 2002 & Tasmania \\
8 & Public Interest Disclosure Act 2003 & Western Australia \\
\hline
\end{tabular}

This chapter distils the major lessons of the present research for current debate about best practice in legislative design. A core reason for the research described throughout this book was to help fill the substantial gap in knowledge as to what a best-practice legislative approach might really be.

In line with this objective, the extensive differences in approach in the existing Australian legislation have already been detailed and compared in an issues paper, Public interest disclosure legislation in Australia: towards the next generation 
(Brown 2006). That analysis showed that while each existing legislative approach contained at least some elements of current best practice, none contained all such elements, and many approaches were clearly deficient by comparative standards. Since then, the pressure for legislative reform has only increased, while some lessons from international reforms have also become clearer. Endorsing the conclusions reached in that paper, an audit by Irene Moss (2007:57), commissioned by Australia's Right to Know Committee, also made a case for greater national uniformity. Positively, the feasibility of adopting a simplified, more targeted legislative approach in Australia has been demonstrated by the second of the above Commonwealth bills, the Public Interest Disclosures Bill 2007, introduced by the Australian Democrats, for which the present research and the 2006 issues paper from this project provided 'the prompt' (Murray 2007).

To assist the search for best practice, this chapter sets out a new basic guide for the minimum content of Australian public sector whistleblowing legislation, in the form of 13 key principles for best-practice legislation. Much of the logic of these principles is set out in the earlier issues paper and not all will be detailed here. Building on the research from the Whistling While They Work project, this chapter identifies three areas in which there is a need for a significant departure from, or extension of, the approaches contained in current legislation.

First, there is a need for legislation to require the implementation of more effective operational systems for the management of whistleblowing. Historically, the Australian legislative focus has been on legal protection of whistleblowers. Important though that is, the research in this book demonstrates that it is equally important to have effective operational systems for managing whistleblowing as and when it occurs. That requires legislative reform in three areas:

- defining the coverage of the act - that is, subject matter and jurisdiction -in a more comprehensive or 'inclusive' manner, to support an 'if in doubt, report' approach to managing disclosures within agencies

- establishing minimum standards for internal disclosure procedures in agencies, particularly for managing the welfare of employees who report

- introducing a new statutory framework for coordinating the management of public interest disclosures, through an external oversight agency and a new relationship between that agency and public sector organisations.

Second, there is a need for legislative reform to address the current lack of practical remedies for public officials whose lives and careers suffer as the result of having made a public interest disclosure. Inevitably, some whistleblowers experience adverse outcomes for which governments should accept responsibility - for reasons of individual and organisational justice and in recognition of the practical need to demonstrate that public interest reporting of wrongdoing is valued. The data indicate that current legislative settings are insufficiently focused on restitution (including financial compensation) as a 
response to adverse outcomes, as opposed to criminal remedies that are, in any event, inappropriate for the bulk of cases. There is also a need for legislation to better define the legal responsibilities of employers for the welfare of employees, including by providing incentives for public sector managers to be more diligent in exercising their duty of care to prevent and minimise adverse outcomes.

Third, legislative reform is needed to provide better protection for public officials who justifiably go public with their concerns. While the research has confirmed that public whistleblowing is statistically infrequent in comparison with internal whistleblowing, it nevertheless does arise and is widely recognised as healthy and sometimes necessary in a mature democracy. Only New South Wales currently has legislative provisions dealing with such circumstances, and then inadequately. The imperative for reopening this aspect of current legislation has been boosted by the Commonwealth Government's commitment to do so. This chapter sets out principles for how a workable formula might be achieved.

The final part of the chapter sets out the key principles for best-practice whistleblowing legislation as a whole, including those issues dealt with in greater detail in earlier parts. These principles reflect feedback on the most important issues identified in the issues paper, the lessons of the empirical research and previous reviews from the academic literature (for example, Latimer 2002a). As with the remainder of this research, these principles have been developed with the public sector in mind, also recognising that in Australia it is the public sector that has had greatest experience to date with statutory public interest disclosure regimes. It could be, however, that these principles can be readily adapted to the private and civil society sectors.

\section{Organisational systems for encouraging and managing whistleblowing}

As outlined in Chapter 1, despite frequent controversy about policy and legislative responses to whistleblowing, the objectives of current public sector whistleblowing laws are relatively consistent and clear (NSW Ombudsman 2004a; Brown 2006:5). As set out in the key principles below, they are:

- to support public interest whistleblowing by facilitating disclosure of wrongdoing

- to ensure that public interest disclosures are properly assessed and, where necessary, investigated and actioned

- to ensure that a person making a public interest disclosure is protected against detriment and reprisal.

There is reason to doubt whether existing legislation is carrying these objectives into practice. Chapter 10 has indicated that the 'symbolic' or communicative purposes of the legislation are having their desired effect. Where awareness of the legislation is higher, attitudes to public interest whistleblowing are more 
positive within organisations and inaction rates in response to wrongdoing tend to be lower. There remains, however, a great deal of uncertainty as to whether legislative protection does or will flow through to measures for the management of whistleblowers. Chapters 4 to 6 reinforce the heavy responsibilities that lie on public sector managers to deliver the third of the above objectives; Chapters 9 and 10, however, show the weak state of current systems and procedures for fulfilling this obligation.

From these analyses, it is apparent that legislative regimes can and should be strengthened to provide more robust systems for managing whistleblowing. Three issues stand out as important, practical foci for reform.

\section{Comprehensive definitions and application}

As set out in the issues paper and elsewhere (NSW Ombudsman 2004a; Brown 2006:8-13, 16-99; Latimer and Brown 2007), some of the most obvious differences between current legislative regimes relate to technical differences in the coverage and jurisdiction of the legislation. These differences affect which public officials - and others, such as family, friends or innocent bystanders - are eligible for protection, to whom they may make a disclosure, the types and seriousness of the wrongdoing that can give rise to protected disclosures and the people and bodies about which disclosures may be made.

While some diversity could be necessary or desirable, the current differences on these issues indicate uncertainty and confusion about the right approach, more than well-informed design. The impacts of these differences can be quite heavy. In general, the distinctions that define coverage and jurisdiction tend to dictate that an unnecessarily fine degree of technical knowledge is needed to calculate whether or not the legislation applies to a given case. At best, these difficulties work against the ability of managers to easily recognise that they have received or are dealing with a disclosure to which the legislation applies. This could explain why the protective measures intended to be triggered by disclosures are triggered only in a small minority of cases-as discussed in Chapter 9.

At worst, however, the technical nature of the coverage given by the legislation can also be helping defeat its purpose, in an operational sense, by causing the number of disclosures that are formally recognised to be minimised. Chapter 2 explained that a conservative estimate of the proportion of all respondents to the employee survey who fitted the definition of public interest whistleblowing was approximately 12 per cent. While this inevitably includes a proportion of less serious wrongdoing, Chapters 5 and 6 demonstrate that the type of wrongdoing involved is not in itself a factor that currently indicates whether there is a risk of mistreatment or conflict, while perceived seriousness is only one of a number of risk factors. If it is to help ensure that public interest 
whistleblowing is appropriately managed, the legislation should operate to maximise - not minimise - the number of whistleblowers whose disclosures trigger official attention.

The data nevertheless indicate that, in practice, the bulk of public interest whistleblowing is occurring without being recorded, monitored or reported under public interest disclosure legislation. The agency survey asked agencies how many internal reports of wrongdoing they had formally identified as public interest disclosures, protected disclosures or whistleblowing reports under the legislation relevant to their jurisdiction in the period 2002-04. Table 11.2 sets out the results, against the estimated incidence of public interest whistleblowing from the employee survey.

Table 11.2 Numbers of formally recognised disclosures compared with estimated whistleblowing levels

\begin{tabular}{|c|c|c|c|c|c|c|}
\hline & \multicolumn{3}{|c|}{ Agency survey results } & \multicolumn{3}{|c|}{ Employee survey (ES) results } \\
\hline & $\begin{array}{l}\text { No. of } \\
\text { agencies } \\
\text { reporting no }_{\text {PIDs }^{\mathrm{a}}}\end{array}$ & $\begin{array}{c}\text { No. of } \\
\text { agencies } \\
\text { reporting PIDs }\end{array}$ & $\begin{array}{l}\text { Total number } \\
\text { of PIDs } \\
\text { reported } \\
(2002-04)\end{array}$ & $\begin{array}{l}\text { Estimated total } \\
\text { employees of } \\
\text { these agencies }\end{array}$ & $\begin{array}{c}\text { Proportion of } \\
\text { ES respondents } \\
\text { who were } \\
\text { public interest } \\
\text { whistleblowers } \\
(2004-06)\end{array}$ & $\begin{array}{l}\text { Estimated total } \\
\text { public interest } \\
\text { whistleblowers }\end{array}$ \\
\hline Cth & 13 & 11 & 377 & 103314 & $11.1 \%$ & 11468 \\
\hline NSW & 23 & 11 & 4631 & 232221 & $12.4 \%$ & 28795 \\
\hline Qld & 18 & 13 & 294 & 168039 & $12.7 \%$ & 21341 \\
\hline \multirow[t]{2}{*}{ WA } & 22 & 3 & 6 & 55402 & $11.0 \%$ & 6094 \\
\hline & 76 & 38 & 5308 & 559076 & $12.1 \%$ & 67698 \\
\hline
\end{tabular}

${ }^{\mathrm{a}} \mathrm{PID}=$ public interest disclosure

Sources: Agency survey: Q24; employee survey: Q26.

Given the similarity between jurisdictions in terms of the proportion of employees observing and reporting wrongdoing, there are few possible explanations for the low and very different rates of formally recognised disclosures. Some difference is explained by jurisdiction-specific factors. For example, only some Commonwealth agencies are covered by the limited whistleblower protection provided by Section 16 of the Public Service Act 1999; while the West Australian legislation began only halfway through the relevant period, in 2003-04. The Australian Public Service Commission (APSC 2004:112) has, however, previously recorded that a 'significant level of confusion' exists around the Commonwealth framework; and, in Western Australia, even in 2006-07, only 14 disclosures by 13 people were formally recognised as having been made under the legislation, for all state agencies (OPSSC 2007:18).

The likely explanation is that even in jurisdictions recording a higher number of disclosures, the majority are still being managed outside the legislation and hence are underreported. The reasons could be because technical definitions are excluding them; because restrictive procedures have been put in place (for example, dealing with disclosures only if they are lodged on a specific form, as 
occurs in Western Australia); or because there is a lack of understanding among agencies and managers, as indicated in Chapter 7, about how the legislation is intended to apply.

A paradox also exists in some jurisdictions where a low proportion of public interest whistleblowing is being formally recognised, but there are liberal definitions of who can be a whistleblower. In Western Australia, Victoria, the Australian Capital Territory and South Australia, literally 'anyone' may make a public interest disclosure, even if they are not a whistleblower in the sense used throughout this book - that is, even if they are not internal to the public sector organisation concerned. In other words, any member of the public may make a public interest disclosure and seek special protective measures, in addition to normal avenues of complaint under other legislation (such as ombudsman legislation).

In these jurisdictions, it appears that this 'open standing' approach has led to the insertion of other restrictions, either in the legislation or in its implementation, in order to limit the potentially huge number of cases that come within the legislation. This appears to explain why it was decided, in Section 3 of the Whistleblowers Protection Act 2001 (Victoria), that the legislation should apply only to disclosures that would, if proved, constitute a criminal offence or reasonable grounds for dismissing a public officer-even though, in other jurisdictions, such high thresholds only apply to, at most, a limited category of disclosures (see Brown 2006:16-18, 65). It also provides the most logical explanation for why disclosures by Victorian public employees about maladministration are not covered by the Act - that is, to prevent the Act also being used by non-internal complainants, such as prisoners, ratepayers and consumers, as an alternative to existing complaint avenues. Nor does the act then provide coverage for public officials who disclose information about defective administration, no matter how serious.

In other jurisdictions, such as New South Wales, there is a related problem that to escape restrictive eligibility criteria, public officials may make disclosures in the form of complaints under other legislation, directly to external integrity agencies such as the Ombudsman or the Independent Commission Against Corruption. These complaints may qualify more easily for similar legal protections. In these contexts, the overly technical approach has again failed, for two reasons: it has encouraged officials to make their disclosures externally even in circumstances in which the agency could be equipped and best placed to act on the disclosure; and, while the alternative legislation could provide legal protection, it is not geared to trigger the vital, internal management protections on which the welfare of most whistleblowers depends.

All these issues combine to suggest that the jurisdiction and coverage of the legislation need to be stripped back to first principles. The principles set out in 
the conclusion take it as a given that the focus of whistleblowing legislation is to detail the special measures required for protecting and managing people internal to an organisation who possess crucial information about internal wrongdoing, but who face great disincentives against revealing it. The criteria for determining when those protective measures are triggered should be no more onerous than the threshold for a person to make a complaint under other legislation. There should be consistency in the basic principles that apply to protect external complainants, whistleblowers and staff involved simply in the handling or referral complaints, so as to minimise the potential for technical barriers to arise that frustrate agencies' ability to extend this protection. Different legislation may be needed, however, to put in place the different requirements for how this protection is to be achieved. In the case of whistleblowing, the legislative threshold should be calibrated to encourage a philosophy of 'if in doubt, report'. This will occur only if those making a disclosure receive appropriate official encouragement.

\section{Minimum standards for agency obligations and procedures}

Further reasons for the underreporting of the bulk of disclosures covered by existing legislation relate to the weak state of procedures and systems within most agencies, in all jurisdictions, for how disclosures should be managed. Even where the legislative approach is comprehensive, it is unlikely to be implemented in a reliable and consistent manner in the absence of clear procedures. Moreover, where procedures are weak, uncertainties prevail as to the implications of recognising an employee's disclosure as being one to which the legislation applies - for example, there can be an erroneous belief that the administrative burden of managing an employee will increase when, in fact, the medium to long-term effects should be that the burden is simplified.

The evidence reviewed in Chapter 10 suggests that when agency procedures are more comprehensive, the response to whistleblowing is likely to be more effective and achieve better overall results. The present standard of procedures, however, remains generally low. This is especially the case in Queensland and Western Australia, notwithstanding that these jurisdictions have the most comprehensive legislation. Across all the agencies studied, only relatively few internal disclosure procedures satisfy the relevant Australian Standard for whistleblower protection (AS 8004-2003) (Standards Australia 2003).

What can be done to lift the standard of agency procedures and systems? Many of the practical lessons emerging from existing experience will be set out in the second report from this project. It is, however, already clear that legislative action is necessary. Table 11.3 provides an outline of the current legislative requirements with respect to agency procedures. Consistent with the analyses in Chapters 9 and 10, even when there are legislative requirements for procedures, these currently often do not extend to procedures for discharging 
all the basic objectives of the legislation, including protection and management of whistleblowers. Of the four instruments that explicitly require agencies to develop procedures for how whistleblowers are to be protected, none specifies any particular guidance or minimum content for these procedures.

\section{Table 11.3 Legislative requirements for internal disclosure procedures}

\begin{tabular}{|c|c|c|c|c|}
\hline \multirow[t]{2}{*}{ Legislation } & \multicolumn{3}{|c|}{ Agency procedures for } & \multirow{2}{*}{$\begin{array}{l}\text { Agency procedures } \\
\text { must follow model } \\
\text { code/guidelines }\end{array}$} \\
\hline & $\begin{array}{l}\text { How disclosures can } \\
\text { and should be made }\end{array}$ & $\begin{array}{l}\text { Investigation of and } \\
\text { action on disclosures }\end{array}$ & $\begin{array}{l}\text { Protection of people } \\
\text { as a result of } \\
\text { disclosures }\end{array}$ & \\
\hline 1. SA 1993 & \multicolumn{4}{|c|}{ Nil } \\
\hline $\begin{array}{l}\text { 2. Old } \\
1994\end{array}$ & $\begin{array}{c}\text { Contemplated, but not } \\
\text { required }\end{array}$ & Nil & Required & $\mathrm{Nil}$ \\
\hline $\begin{array}{r}\text { 3. NSW } \\
1994\end{array}$ & $\begin{array}{c}\text { Contemplated, but not } \\
\text { required }\end{array}$ & Nil & Nil & Nil \\
\hline \begin{tabular}{|l|l|} 
4. & ACT \\
1994
\end{tabular} & Required & Required & Required & Nil \\
\hline $\begin{array}{l}\text { 5. Cth } \\
1999\end{array}$ & Required & Required & Nil & Nil \\
\hline \begin{tabular}{|l|} 
6. Vic \\
2001
\end{tabular} & Required & Required & Required & Ombudsman guidelines \\
\hline $\begin{array}{l}\text { 7. Tas } \\
2002\end{array}$ & Contemplated & Nil & Nil & Nil \\
\hline $\begin{array}{l}\text { 8. WA } \\
2003\end{array}$ & Req & uired & Required & $\begin{array}{l}\text { Commissioner } \\
\text { guidelines }\end{array}$ \\
\hline
\end{tabular}

Source: Brown, A. J. 2006, Public interest disclosure legislation in Australia: towards the next generation, Issues paper, Commonwealth Ombudsman, NSW Ombudsman and Queensland Ombudsman, p. 46.

While Western Australia's approach remains operationally problematic, its legislation does provide the benchmark for making clear that the protection of public interest whistleblowers represents a basic test of management. Section 23(1)(b) of the Public Interest Disclosure Act 2003 (WA) places a positive obligation on the principal executive officer of all public authorities to 'provide protection from detrimental action or the threat of detrimental action for any employee... who makes an appropriate disclosure of public interest information'.

In other jurisdictions, positive obligations regarding implementation of the legislation are inserted into other parts of the public sector management framework. In New South Wales, for example, the Model Contracts for Chief Executives and Senior Executives stipulate that their responsibilities include to 'ensure employees are aware of the procedures for making protected disclosures and of the protection provided by the Protected Disclosures Act 1994' (in respect of chief and senior executives) and to 'ensure satisfactory introduction and operation of...reporting systems (including protected disclosures)' (in respect of chief executives). In line with the evidence in Chapter 7, however, it is unclear whether senior executives are presently sufficiently aware of how to fulfil these obligations. 
Several of the principles below-especially Principles 5, 6, 11 and 12-spell out the ways in which best-practice legislation can more clearly identify the key responsibilities of all public sector agencies, which can be implemented through agency systems and procedures. These include systems for ensuring that employee reports of wrongdoing, including all possible public interest disclosures, are comprehensively recorded, tracked and reported, so that accurate management information is available to support an early intervention approach to problems. For the reasons set out in Chapters 6 and 9, there is also a need for more comprehensive agency procedures for assessment of reprisal risk, at the outset of matters, as well as closer coordination between line managers and internal specialist integrity units in how risks are to be managed.

Much of the current legislation was drafted at a time when it was assumed that the welfare of public employees was best left to the chief executives of individual agencies to manage, unassisted by statutory guidance or external oversight. The findings from this research demonstrate that while that is generally desirable, the risks of conflict and reprisal inherent in whistleblowing require a more structured understanding of the responsibilities of all managers, even if there still can and should be flexibility in how these responsibilities are discharged in practice.

\section{Central clearing house, monitoring and oversight role}

The third operational development needed is improved coordination and monitoring of the management of whistleblowing on a sector-wide basis. Chapters 4 to 6 demonstrate the heavy responsibility that lies on agencies to deal productively with the bulk of current public interest disclosures. While this responsibility is often being met, this is typically in simpler cases, and often due to informal systems and procedures rather than through the planned programs of agencies. The variability in outcomes and in the quality of agency procedures further mitigate in favour of a more consistent and coordinated approach, in which public employees and the general public can have greater confidence that disclosures are being managed in a fair and professional manner.

In general, it might be expected that these quality-assurance roles will be naturally fulfilled as a result of the fact that employees may have recourse to external integrity agencies if dissatisfied with their agency's handling of the matter. The data in Chapters 4, 5, 6, 8 and 9 indicate, however, the need to revisit this assumption. In particular, it appears clear that the majority of employees have a natural tendency to blow the whistle internally, to their line managers, rather than using other avenues - even when, in hindsight, they might recognise this to have been unwise. It is also clear that many employees will let a disclosure drop rather than pursue it outside and that, when reprisals or other mistreatment do cause them to pursue it with an external integrity agency, the level of conflict 
has often already become such that any opportunity for the external agency to usefully intervene has passed.

These indications were supported by other results from the integrity case-handlers survey. While 53 per cent of case study agency case-handlers and managers indicated that it was 'often' or 'always' the case that employees who reported wrongdoing experienced 'emotional, social, physical or financial' problems, this figure rose to 72 per cent among the integrity agency case-handlers. While it could be that case-handlers in integrity agencies have a greater awareness of the problems experienced by whistleblowers, an alternative explanation is that by the time cases reach the integrity agencies, they have indeed become more problematic. A majority of integrity case-handlers also estimated that at least half of all reporters were treated badly by their management (20 per cent estimated 'about half', 23 per cent estimated 'about three-quarters' and 17 per cent estimated 'all or almost all'). While Chapter 5 shows this to be a pessimistic assessment of average outcomes at an agency level, it could be an accurate indicator of the state of cases by the time they reach integrity agencies.

The issues paper canvassed some of the basic areas in which greater coordination might be fruitful (Brown 2006:51-4). At present, legislation supports a coordinated approach in only two of the jurisdictions participating in the project. In Western Australia, as seen earlier, the Public Sector Standards Commissioner is responsible for setting the standards for agency procedures and also monitors but does not intervene in individual cases. In Victoria, the ombudsman sets the standard for agency procedures and acts as a clearing house for individual cases, while also having the power to take over or advise on investigations or the management of the individuals involved.

While there are a number of ways in which the Victorian arrangement can be improved (Brown 2006:28-30), it provides the logical departure point for a more systematic approach. Under such an approach, an efficient regime of 'mandatory reporting' would be adopted-akin to the regimes operating successfully in respect of much of the other business of key integrity agencies - in which agencies bring the details of their internal case load to the attention of an external oversight agency on a routine basis, before problems emerge, rather than waiting for problems to emerge ex post facto.

In the most recent review of the NSW legislation, the relevant NSW Legislative Assembly Committee (NSW Legislative Assembly 2006:10-11, 36-7) similarly recommended the creation of a Public Interest Disclosures Unit within the Office of the Ombudsman, 'funded by an appropriate additional budgetary allocation', to: 
a. provide advice to people who intend to make, or have made, a disclosure

b. provide advice to public authorities on matters such as the conduct of investigations, protection for staff and general advice

c. provide advice and assistance to public authorities on the development or improvement of internal reporting systems

d. audit the internal reporting policies and procedures of public authorities

e. monitor the operational response of public authorities, including a requirement for all public authorities including other integrity agencies to notify the unit of all disclosures received that appear to be protected under the act

f. act as a central coordinator for the collection and collation of statistics on disclosures

g. publish an annual report containing statistics on disclosures and identifying any systemic issues or other problems with the operation of the act

h. coordinate education and training programs and provide advice to public authorities seeking assistance in developing internal education programs

i. publish guidelines on the act

j. develop proposals for reform.

It is important that an independent agency with existing expertise in investigations and case-handling takes on these coordination roles. It is clear that, in addition to compliance, reporting and advisory roles, this oversight agency must be empowered to act in the shoes of line agencies in circumstances in which action is needed-for example, to ensure effective investigations or effective responses in cases of reprisal or breakdown in the ability of agencies to support and protect their employees.

The importance of building a more effective, operational relationship between public agencies and the relevant integrity agencies is reflected below in Principles 7, 12 and 13. The development of such arrangements is not necessarily a simple process. As recognised by the NSW review, it requires resources and the building of capacity within the oversight agency on many of the practical and human resource management issues relevant to the prevention and minimisation of reprisals and other internal conflicts. It also requires the support and participation of all integrity agencies through a coordination steering committee. Despite these challenges, the development of such a role and its entrenchment in legislation provides a further important key to achieving more effective operational systems for the management of whistleblowing.

\section{Realistic compensation mechanisms}

A primary objective of whistleblowing legislation is to provide legal protection to officials who make public interest disclosures. In Australia, legal protection frequently takes four forms: 
- relief from criminal liability for breach of statutory secrecy provisions, as just discussed

- relief from civil liability for, for example, defamation or breach of confidence

- protection from disciplinary or other workplace sanctions, such as reduction in salary or position or termination of employment, resulting from the disclosure

- legal redress for any detriment suffered as a result of making the disclosure.

This last form of protection, legal redress, itself takes two forms. In every jurisdiction other than the Commonwealth and South Australia, it is a criminal offence for any person (in Queensland, any public officer) to undertake a reprisal as a result of the making of a public interest disclosure (Brown 2006:37). In all jurisdictions other than the Commonwealth and New South Wales, a person who suffers detriment is also entitled to sue a person or body responsible for detriment in the Supreme or District Court. This can be by way of a tort action under personal injuries law or (in South Australia and Western Australia) as an action for victimisation under equal opportunity legislation (Brown 2006:40). Table 11.4 sets out the availability of these different civil remedies.

Table 11.4 Current civil, industrial and equitable remedies

\begin{tabular}{|c|c|c|c|c|}
\hline Legislation & Civil action (tort) & Equal opportunity/ & Workplace relations & Injunctive relief \\
\hline 1. SA 1993 & Yes & $\begin{array}{c}\text { Equal Opportunity } \\
\text { Act } 1984\end{array}$ & No & No \\
\hline Old 1994 & Yes & $\begin{array}{c}\text { Unfair treatment of } \\
\text { office }\end{array}$ & $\begin{array}{c}\text { Industrial Relations } \\
\text { Act 1998, unfair } \\
\text { dismissal }\end{array}$ & Yes \\
\hline 3. NSW 1994 & \multicolumn{4}{|c|}{ No (common law only) } \\
\hline АCT 1994 & Yes & No & No & Yes \\
\hline 5. $\quad$ Cth 1999 & No & $\begin{array}{l}\text { Victimisation or } \\
\text { discrimination }\end{array}$ & No & No \\
\hline 6. Vic 2001 & Yes & No & No & Yes \\
\hline 7. Tas 2002 & Yes & No & No & Yes \\
\hline 8. WA 2003 & Yes & $\begin{array}{c}\text { Equal Opportunity } \\
\text { Act } 1984\end{array}$ & No & No \\
\hline
\end{tabular}

Source:Brown, A. J. 2006, Public interest disclosure legislation in Australia: towards the next generation, Issues paper, Commonwealth Ombudsman, NSW Ombudsman and Queensland Ombudsman, p. 40.

A second major issue for legislative action, arising from this research, is the need to develop a more effective mechanism for providing such remedies-including ensuring that appropriate compensation flows to those public employees whose lives and careers do suffer as a result of disclosures. Chapter 5 demonstrated that adverse career and life outcomes from whistleblowing were a significant issue, even for purely internal whistleblowers. Chapter 3 demonstrated the powerful effect that anticipated reprisals had in dissuading officials from speaking up about wrongdoing. Chapters 6, 9 and 10 also showed that currently, many agencies are doing little - in any organised way - to ensure that employees who report wrongdoing are supported and protected. The data from the case study 
agencies confirm that many case-handlers and managers believe their agencies are not currently achieving a great deal of success in their handling of the problems experienced by whistleblowers.

The data from the case study agencies also point to some clear explanations for this relative lack of success. In Chapter 5, it was seen that the bulk of mistreatment experienced by public interest whistleblowers resulted from the acts and omissions of management, rather than individual co-workers and colleagues, as once widely believed. The most frequent types of detriment or harm are also not discrete acts to which criminal liability is readily attached, even if the responsible people can be identified. Rather, the most frequent and problematic forms of detriment involve adverse outcomes related to deteriorations in the workplace environment and in employment conditions and prospects. These are likely compounded by subjective factors such as unmanaged stress, especially when there is failure in active support. Wherever there is a history of dysfunction in the immediate workplace, or a whistleblower's work performance suffers as a result of their involvement in the process, it can be difficult to distinguish between management actions against a whistleblower that would (in other circumstances) be reasonable and management responses that are not acceptable. The unacceptable response can take the form of a deliberate reprisal, an attempt to dispose of a troublesome case or a de facto cover-up of the manager's own failure to deal with matters effectively in the first instance.

In many circumstances, a compensatory approach to the problems experienced by a whistleblower will provide the only effective remedy. In contrast, the attempt to investigate and prosecute an individual manager for having undertaken a deliberate reprisal - especially to a criminal standard of proof - is only occasionally likely to be a feasible or fruitful exercise. Criminal prosecutions for reprisal are known to have been attempted only against individual colleagues and, even so, have been few in number and are yet to lead to any convictions.

Given these realities, it is crucial that there be effective avenues for providing restitution to aggrieved employees, including financial compensation where necessary. It is clear that public sector agencies, as employers, do have a legally enforceable duty of care to support and protect those employees who fulfil obligations to report wrongdoing within the organisation. Damages might be payable for a failure to take reasonable steps to meet that duty. This duty exists in common law, irrespective of public interest disclosure legislation; this much is demonstrated in New South Wales, where, as seen in Table 11.4, there is no legislative avenue for compensation. Nevertheless, in 2001, the District Court of New South Wales found in Wheadon $v$. State of New South Wales ${ }^{1}$ that the NSW Police Service was liable for damages of \$664 270 for having breached its duty of care to one officer, who had reported suspected corrupt conduct. The 
officer experienced harassment and victimisation resulting in serious stress culminating in psychiatric illness. The breaches for which the agency was held liable included:

- failure to give support and guidance to the plaintiff

- failure to provide the plaintiff with a system of protection (including active steps to prevent or stop harassment and persecution)

- failure to properly investigate the plaintiff's allegation

- failure to properly investigate allegations against the plaintiff

- failure to assure the plaintiff that he had done the right thing by reporting corruption.

In contrast with this common-law duty, no whistleblower in a jurisdiction with a statutory compensation mechanism is known to have ever succeeded in gaining compensation. Comparative analysis and case law provide some indication of the reasons why. A general problem is that these statutory mechanisms do not locate the avenue for enforceable legal compensation within the employment relationship, where the duty of care is most obvious, as shown by Wheadon $v$. State of New South Wales. Rather, as seen in Table 11.4, the statutory mechanisms equate the damage suffered by a whistleblower to a personal injury suffered by the individual as the result of negligence by another individual (for example, as if in a car accident). The burden of establishing the nature of the duties involved, combined with the costs of taking legal action in an intermediate or superior court, combined with the risk of a costs order should the action fail, are all enough to explain why whistleblowers would seek to live with adverse outcomes rather than seek compensation.

As also seen in Table 11.4, when an alternative compensation mechanism is provided, such as under equal opportunity legislation, it is usually no more appropriate. While providing a lower cost and potentially more flexible forum, equal opportunity tribunals are geared to mediating and remedying discrimination against employees based on identified characteristics (gender, race, age, disability, sexual orientation). They are less well placed to find responsibility for failures in an employer's duty of care to protect an employee, who could be any employee depending on the circumstances.

It is conspicuous that only one jurisdiction, Queensland, provides a direct statutory link between whistleblower protection and workplace relations law, by providing that an employee may challenge their dismissal as unfair when that action has been taken as a result of their having made a public interest disclosure (Industrial Relations Act 1998 (Qld), s. 73(2)(f)(i)). This remedy is, however, limited to dismissal and does not provide a mechanism for compensation in respect of any detriment short of dismissal, nor for any acts or omissions of agency management constituting a failure to support or protect the employee. 
Also in Queensland, two cases demonstrate the inadequacy of the current personal injury-based compensation provisions, in their juxtaposition with the criminalisation of reprisals. In 2000, the Queensland Court of Appeal found in Howard $v$. State of Queensland that a whistleblower's entitlement to seek damages under section 43 of the Whistleblower Protection Act 1994 did not extend to an entitlement to establish that their employer was vicariously liable for the detriment that they had suffered. The primary reason given by the court was that Section 42(2) of the act also made the detrimental action a criminal offence, triggering the problem that '[i]llegal acts committed by an employee which are inimical to the purposes of the employment are regarded as falling outside the course of employment and no vicarious liability falls upon the employer for them'. ${ }^{2}$ According to Thomas, J. A., the 'direct liability of a public sector entity for its own acts' marked the limits of the civil law liability that the act envisaged on the part of a public sector entity, meaning that the tort identified in section 43 could 'be committed only by the direct acts of a person or corporation', with 'vicarious liability for the acts of others...excluded'.

Ironically, the Court of Appeal also found this situation to have been reinforced, rather than ameliorated, by the fact that section 44 of the act cast a duty on a public sector entity to establish reasonable procedures to protect its officers from reprisals. The net effect of the decision was to limit the extent to which the compensation provisions of the act could extend to breaches of an employer's duty of care to prevent, minimise or remedy the detrimental actions of its employees and managers. Instead, the compensation provisions become little more than a 'victim compensation' mechanism in the so-far unlikely event that a criminal prosecution for reprisal ever succeeds.

A second Queensland case confirms the confused relationship that exists between the law of whistleblower compensation and general workplace relations law. In Reeves-Board $v$. Queensland University of Technology, the Supreme Court of Queensland found that since the tort of reprisal under the Whistleblower Protection Act 1994 provided for 'damages for personal injury by an employee from an employer to which the employment was a significant contributing factor', any action for compensation must also comply with the requirements of the subsequent WorkCover Queensland Act 1996-leading the court to strike out those parts of the whistleblower's claim seeking damages for personal injury. ${ }^{3}$ The decision confirms that the correct basis for whistleblowing compensation claims lies in the employment relationship, but reduces this to a subset of existing, traditional compensation mechanisms for injury.

Significantly, the opposite result was recently obtained in Victoria, where, in Owens v. University of Melbourne and Anor (2008), the Supreme Court found that nothing in the Accident Compensation Act 1985 (Vic.) limited the right of a whistleblower to seek damages from her employer under section 19 of the 
Whistleblowers Protection Act 2001 (Vic.). ${ }^{4}$ This was partly because, unlike in Queensland, in Victoria, the whistleblowing legislation had come after the relevant workers' compensation legislation. More importantly, the court also recognised the different purposes and nature of the legislation, with the existing workers' compensation legislation addressed to 'serious injury' meaning 'any physical or mental injury', including such things as industrial deafness and workplace-triggered diseases - while the whistleblowing legislation was aimed at a broader conception of employers' responsibilities:

Detrimental action [under the Whistleblowers Protection Act 2001] includes injury but importantly, extends to what may be described as collateral damage to a person's career, profession or trade, all of which may be apt to describe aspects of loss and damage suffered by employees as well as other classes of person. The breadth of the compensable loss and damage under the Act defines the cause of action within an entirely different category to claims under the Accident Compensation Act, notwithstanding an overlap that might occur in the case of injury...In my opinion s 19 creates a new, novel and additional class of rights and remedies to those which already existed...for work related injury...

The purpose of the Act would be frustrated if those who suffered detrimental action in the workplace were denied the full range of remedies available under the Act merely because any injury they suffer arose out of or in the course of their employment. ${ }^{5}$

While the Victorian case reached a more beneficial result, the fact that this last statement was needed further underscores the extent to which the right to compensation under public interest disclosure legislation has been dislocated, in general in Australia, from the basic responsibilities of public agencies as employers.

The Australian confusion suggests a need to strip back current legislative provision to first principles - or create them, in the case of the Commonwealth - in two ways. First, it should be made express in the legislation that the criminal offence of reprisal, provable beyond reasonable doubt, does not limit the entitlement of a whistleblower to seek compensation for detriment suffered, whether criminal or non-criminal. In other words, to escape the consequence experienced in Queensland in Howard, but consistent with Wheadon, it should be clear that employers can indeed by held vicariously liable for the acts and omissions of individual staff, direct or indirect, whenever detriment follows and there has been a breach of an individual or organisational duty of care. It should also be made clear that normal evidentiary principles apply - that is, that a claim for compensation may be satisfied based on a balance of probabilities, irrespective of the criminal standard. Consequently, it should be made possible to conclude, on a balance of probabilities, that detriment 
occurred and that the organisation may therefore owe remedial action, even if individuals cannot be identified as criminally liable.

Second, a more appropriate compensation avenue should be found than those presently existing under Australian legislation. In particular, as set out in Principle 12 below, the assumption should be revisited that the appropriate compensation mechanism is by way of application to a superior court, in a manner analogous with personal injuries. The guiding principle should be that an employer's workplace responsibilities include a duty to ensure that detrimental acts and omissions do not occur and to protect and support employees in the face of risks of detrimental action.

This alternative approach is taken in the United Kingdom; other jurisdictions such as South Africa and Japan follow a similar model. The Public Interest Disclosure Act 1998 (United Kingdom) created neither criminal offences of reprisal nor compensation mechanisms based on tort law. Instead, it simply amended the Employment Rights Act 1996 (United Kingdom) so as to entitle employees to compensation from their employers for detriment suffered as a result of the making of a disclosure (see Gobert and Punch 2000; Calland and Dehn 2004; generally, <www.pcaw.co.uk>). The location of the mechanism within workplace relations law makes clear that this entitlement exists alongside, rather than as a subset of, existing workers' compensation schemes. The forum for determination of compensation applications is the British system of Employment Appeals Tribunals, akin to Australian industrial relations commissions, rather than courts of law. Damages may be pursued for actions short of dismissal, they are uncapped and are assessed according to what is 'just and equitable in all the circumstances', having regard to the infringement complained of and any loss suffered by the worker (Employment Rights Act 1996 (United Kingdom), s. 49(2)).

The British scheme applies to most public sector and all private sector employers - as is possible under a unitary workplace relations system. Nevertheless, irrespective of how Australia's workplace relations might evolve (see Brown and Latimer forthcoming), the principles of this approach have clear application to all Australian jurisdictions in respect of protection of government employees. It is meaningless to offer a legislative avenue for compensation if the avenue offered is unnecessarily difficult and carries undue risks of further stress and detriment in the form of exposure to costs. An efficient compensation mechanism, on the other hand, will not only deliver justice more easily in deserving cases, it will provide a powerful incentive for agencies to limit their potential exposure by taking more effective action to prevent employees from suffering detrimental responses in the first place. The research has shown not only that the original intent of Australian legislatures in respect of compensation has not been achieved, but that such incentives for prevention of reprisals and other conflict are badly needed. 


\section{Recognising public whistleblowing}

\section{The case for reform}

In statistical terms, as shown by Chapter 4, the bulk of whistleblowing in relation to Australian public sector agencies occurs internally. Very little involves disclosure to the media or other third parties, other than in circumstances in which agencies and external integrity agencies have failed to act - at least in the view of the public employee blowing the whistle.

For a range of reasons, it is appropriate that public interest disclosure legislation should continue to be framed around the principle that public officials should first disclose suspected wrongdoing to internal authorities, or to relevant integrity agencies. In many cases, the managers in public sector agencies are the best placed to act on a problem in a timely manner. The results in Chapter 5 indicate that this often occurs. The prevalence of internal whistleblowing also suggests that most employees who make a disclosure do not wish to pit themselves against the organisation, embarrass their agency or colleagues unnecessarily or seek celebrity.

Nevertheless, the focus on encouraging disclosures to management and to integrity agencies should not be limited, as it presently usually is, to the exclusion of public whistleblowing. Internal, regulatory and public whistleblowing should not be mutually exclusive options. Rather, the last avenue needs to be recognised as available should either of the first two avenues fail. It is clear that the successful management of whistleblowing as a process hinges in part on the confidence of employees and the understanding of agencies that if authorities fail to act, a further disclosure could be justified and, if so, will still attract legal protection. It is well documented that when agency systems break down and wrongdoing cannot be reported internally with safety, or authorities do not act in a timely manner, public whistleblowing may be the only way in which effective action is triggered (for example, Gibbs 1991; Senate Select Committee on Public Interest Whistleblowing 1994; Davies 2005).

At present, in Australia, only the NSW legislation reflects this reality (s 19). While the NSW provisions are far from best practice (Brown 2006:43-4; Brown 2007), it is noteworthy from Chapter 10 that NSW government agencies currently have, on average, the most comprehensive procedures for managing whistleblowing and, on average, a range of outcomes that is at least as good as any other jurisdiction. These results come notwithstanding that the remainder of the NSW legislation is weak in many areas, including no statutory framework for agency procedures and no mechanisms for compensation. While there could be several explanations for the relative quality of NSW agency procedures, the presence of the risk that a public disclosure will be recognised is, on anecdotal evidence, a significant part of the explanation. Even the mere risk that a 
whistleblower will legitimately repeat their disclosure to the media is a motivating factor in convincing agencies to deal with internal disclosures seriously.

Since the present research began, public and official opinion has fortunately moved significantly towards recognition of the importance of extending legal recognition to justified public whistleblowing. In part, this has been prompted by a number of prosecutions of Commonwealth officials for breaching criminal prohibitions on the release of official information to third parties, including at least one instance in which the prosecution was widely seen as contrary to the public interest (the case of Australian Customs official Alan Kessing; see Brown 2007). Such cases have made clear that without legislative reform through public interest disclosure legislation, it is questionable whether an official will ever claim any kind of public interest immunity from criminal prosecution, no matter what the circumstances. In October 2007, an audit of government secrecy laws by Irene Moss, conducted for Australia's Right to Know Committee, concluded that public interest disclosure legislation 'should at least protect whistleblowers who disclose to the media after a reasonable attempt to have the matter dealt with internally or where such a course was impractical' (Moss 2007:73). At the same time, recognising that much of the media operates across more than one jurisdiction, the Moss audit concluded in favour of a uniform national legislative approach, led by a 'new model Commonwealth law'.

While these recommendations are welcome, it is important to note that different philosophical approaches can inform these desired outcomes. From a news media perspective, restrictions on officials' ability to disclose official information are often seen as restrictions on free speech, given that in practical terms they operate as a restriction on the ability of the media to receive and report on matters of potential public interest. In Canada, the legal principles have also been traditionally seen as involving a balance between a public servant's freedom of expression and their duty of loyalty. ${ }^{6}$ In Australia, the notion that public officials possess a 'right' to blow the whistle on matters they consider important has also gained encouragement from the Bennett case, in which the Federal Court ruled that APS regulations prohibiting disclosure of information by a union official transgressed the implied constitutional freedom of political communication. ${ }^{7}$ At the Prime Minister's Australia 2020 Summit, held in April 2008, the imperative for 'whistleblower protection to be respected and strengthened' was also bracketed as one item for a new 'Charter of Free Speech' (Commonwealth of Australia 2008:310).

Protection of public whistleblowing should be understood as something more than the protection of freedom of speech. Its underpinnings lie as much in the duty of loyalty that is owed by public officials to their employing organisation, and ultimately to the community. All employees, and especially public officials, have a duty to report perceived wrongdoing of which they are aware. As seen 
in Chapters 3 and 4, a willingness to report wrongdoing is consistent with high standards of organisational citizenship, including loyalty, for most employees in most organisations. An official who blows the whistle to an integrity agency is also seen as upholding the public interest, even if this act places them in tension with their own management. Protection should be given to employees who engage in public whistleblowing arising from their sense of duty to report wrongdoing, when the public disclosure is the only avenue reasonably available for ensuring that the matter is addressed.

An incidental benefit of recognising public whistleblowing is that it could relieve public confusion about the differences between whistleblowing and 'leaking' or other forms of unauthorised disclosure (such as selling state secrets). The media often treats these different forms of disclosure as essentially similar. There can be a fine line between anonymous public whistleblowing and mere 'leaking', but there is a difference that should be reflected in workable legal formulae. There is a need for rules that can be applied in individual cases by public employees, governments, prosecuting authorities, courts and tribunals to determine whether a disclosure is a reasonable attempt by an official to discharge their duty of loyalty to the public interest, to have perceived wrongdoing rectified or is an act driven purely by other motives, whether personal, political or financial.

When governments prosecute or discipline their own employees for disclosing official information, this inevitably has a major dampening effect on the willingness of employees to speak up about wrongdoing, via any channel. Workable rules for recognising public whistleblowing will help encourage disclosures via appropriate channels and will make it easier for authorities to establish when action against an official who discloses information is justified.

\section{The nature of reform}

Principle 10, below, includes the recognition of public whistleblowing as a key and necessary element of best-practice legislation. How this principle is best implemented remains an issue for analysis and debate; this much is demonstrated by the new Commonwealth Government's important commitment in this area, modelled on the existing NSW precedent. The Commonwealth commitment foreshadows two tests:

In situations where there may be compelling reason requiring disclosure [to third parties such as journalists], a court will be able to weigh up all the relevant factors and balance the public interest in disclosure against any breach of confidentiality which may have occurred.

In these cases, there will be two key tests to determine when public interest disclosure will attract legal protection. Firstly, where the whistleblower has gone through the available official channels, but has 
not had success within a reasonable timeframe and, secondly, where the whistleblower is clearly vindicated by their disclosure. (ALP 2007)

It is not clear from that summary whether a person must satisfy either or both tests in order to gain legal protection. If both tests must be satisfied, and particularly the second test, the scope of protection could be very narrow. The first test reflects the principles embodied in sub-section 19(3) of the Protected Disclosures Act 1994 (NSW), which provides that before a disclosure to a parliamentarian or journalist can attract protection, it must first have been made to an official person who either did not investigate, did not tell the person within six months whether or not it was to be investigated, did not complete the investigation within six months or did not recommend any action. This first test is broadly reasonable, although a question arises about the time limits, discussed further below.

The second test is more difficult to satisfy. It reflects the principles in subsections 19(4) and (5) of the NSW legislation that a whistleblower must also have reasonable grounds for believing the disclosure is 'substantially true' and that the disclosure must indeed be substantially true. This 'substantially true' requirement is a blunt and difficult method for gauging whether public disclosure is justified.A disclosure may be reasonable even if authorities still refuse to act after public pressure. Proving that an allegation of wrongdoing was 'substantially true' may also be a difficult challenge, particularly if the whistleblower has to satisfy a court or tribunal of this matter when seeking compensation or resisting criminal prosecution or civil action. The court or tribunal may also be placed in the position of having to determine the truth of the whistleblower's public allegation, possibly on the basis of evidence led primarily by the whistleblower. In the worst of all worlds, the court or tribunal could rule that the whistleblower acted reasonably, based on a reasonably held belief or suspicion regarding the wrongdoing, but that the truth of the allegation cannot be substantiated. In summary, it could be invidious and impractical to require both tests to be satisfied in order for a person to gain legal protection.

Consideration should also be given to using other criteria as a test for legal protection. Another circumstance in which public disclosure might be reasonable is when investigation is occurring, but too slowly, and there is a 'serious, specific and immediate danger' to public health or safety (Solomon 2006:157, 163). As that suggests, strict time limits should not apply in the test for legal protection: these can be incompatible with a genuine emergency. Recent Canadian legislation provides for public disclosure in such circumstances in section 14 of the Public Interest Disclosure (Whistleblower Protection) Act 2007 (Manitoba), the Public Interest Disclosure Act 2007 (New Brunswick) and section 16 of the Canadian Public Servants Disclosure Protection Act 2005. 
The UK Public Interest Disclosure Act 1998 provides for further disclosure beyond the whistleblower's employer or a regulatory agency, if the disclosure is reasonable in all the circumstances, is not made for personal gain and meets one of four preconditions, either that: 1) the whistleblower reasonably believed he or she would be victimised; 2) there was no prescribed regulator and he or she reasonably believed the evidence was likely to be concealed or destroyed; 3) the concern had already been raised with the employer or a prescribed regulator;

or 4) the concern was of an exceptionally serious nature. ${ }^{8}$ A refined formulation was suggested in Australia in Senator Andrew Murray's private member's bill of June 2007.

These alternative formulations show that there is a range of more flexible options for legal protection of public whistleblowing than currently applies in Australia. The key principle is not whether the whistleblower has been vindicated, but whether the public disclosure is reasonable in all the circumstances. It is well established that if authorities fail to act on an initial disclosure through proper channels, a further disclosure could be reasonable. Other circumstances, however, could also need to be allowed for, including those in which it is not reasonably open to the official to make a disclosure internally or to an integrity agency.

No existing law provides a best-practice model for managing the complex issues that confront public officials who possess information about official wrongdoing or incompetence, in circumstances in which action can reasonably depend on disclosures made outside official channels. This situation has been brought into sharp relief at a Commonwealth level, but, in fact, state whistleblower protection laws also currently provide no better solution. There is, however, real potential for a new legislative response that can deliver a workable balance on this inherently complex issue. How to best allow for such circumstances requires careful consideration.

\section{Best-practice legislation: the key principles}

\section{Overview}

These 13 principles outline the essential features of effective public interest disclosure legislation. The principles are framed to apply to public sector agencies because of the research focus of the Whistling While They Work project. The principles can nevertheless apply, with some modification, to the private sector and to non-government agencies. The unifying theme of the principles - that a person has a right to protection if they complain or disclose information about unacceptable activity occurring in an organisation - imposes like obligations on all organisations in society.

The principles are designed to apply to any employee, contractor or other person working in a public sector agency. The principles are not designed to apply to disclosures or complaints made by members of the public, such as clients and 
customers of an agency. Members of the public warrant comparable protection, but when it does not already exist, separate legislation may be required for that purpose. Equally, there are specific situations for which a tailored scheme may be required to protect people against reprisal or detriment by reason of making a complaint, such as patients or aged persons in a nursing home.

\section{Principles}

\section{Objectives and title}

The stated objectives of public interest disclosure legislation should be:

- to support public interest whistleblowing by facilitating disclosure of wrongdoing

- to ensure that public interest disclosures are properly assessed and, where necessary, investigated and actioned

- to ensure that a person making a public interest disclosure is protected against detriment and reprisal.

These objectives should be captured in the short and long title of the legislation. The Public Interest Disclosure Act is a preferred title to 'Whistleblower Protection Act' or 'Protected Disclosures Act'.

\section{Subject matter of disclosure}

Legislation should specify the topics or types of proscribed wrongdoing about which a public interest disclosure may be made. The topics should cover all significant wrongdoing or inaction within government that is contrary to the public interest. The topics should include:

- an alleged crime or breach of the law

- official corruption, including abuse of power, breach of trust and conflict of interest

- official misconduct

- defective administration, including:

- negligence or incompetence

- improper financial management that constitutes a significant waste of public money or time

- any failure to perform a duty that could result in injury to the public, such as an unacceptable risk to public health, public safety or the environment.

\section{Person making disclosure}

A disclosure should qualify as a 'public interest disclosure' if either of two tests is satisfied: 
a. the person making the disclosure holds an honest and reasonable belief that the disclosure shows proscribed wrongdoing (the subjective test)

b. the disclosure does show, or tends to show, proscribed wrongdoing, irrespective of the person's belief (the objective test).

The motivation or intention of the person making the disclosure should not be relevant. Nor should a person be required to use a special form or declare that it is a public interest disclosure.

\section{Receipt of disclosure}

Legislation should allow a public interest disclosure to be made to a variety of different people or agencies, including:

- the immediate or any higher supervisor of the person making the disclosure

- the CEO of the agency

- any designated unit or person in an agency

- any dedicated hotline, including external hotlines contracted by an agency

- any external agency with jurisdiction over the matter (for example, ombudsman, corruption commission, auditor-general or public sector standards commissioner).

\section{Recording and reporting}

All public interest disclosures to an organisation should be formally recorded, noting the time of receipt, general subject matter and how the disclosure was handled. Recording systems, including required levels of detail, will vary according to agencies' circumstances, but should be consistent with minimum standards across the public sector (see Principle 7).

\section{Acting on a disclosure}

An agency receiving a disclosure should be obliged:

- to assess that disclosure and take prompt and appropriate action, which can include investigating the disclosure or referring it to an external agency

- to the extent practicable and reasonable, to keep the person who made the disclosure informed of action proposed to be taken, the progress of any action and the outcomes of any action

- to include in its annual report a summary of the numbers of public interest disclosures received and the action taken.

\section{Oversight agency}

One of the external agencies with responsibility for public interest disclosures should be designated as the oversight agency for the administration of the legislation. The responsibilities of the oversight agency should include: 
- being notified by agencies of all disclosures and recording those disclosures and how they were dealt with and resolved

- having the option to decide, on being notified of a disclosure, to provide advice or direction to an agency on how the disclosure should be handled, to manage the investigation of the disclosure by the agency or to take over the investigation of the disclosure

- providing advice or direction to agencies on the steps that should be taken to protect people who have made disclosures, or to provide remedial action for a person who has suffered detriment as a result of making a disclosure

- promoting the objectives of the legislation, within government and publicly, and conducting training and public education

- publishing model procedures for the administration of the legislation, with which agencies' internal procedures must be consistent

- conducting a public review of the operation of the legislation at least once every five years.

\section{Confidentiality}

Disclosures should be received and investigated in private, so as to safeguard the identity of a person making a disclosure to the maximum extent possible within the agency's control. Avenues should be available for disclosures to be made confidentially and, where practical, individual disclosures should be dealt with in ways that do not disclose the identity of the person making the disclosure, and preferably even that a disclosure has in fact been made. This principle is subject to the need to disclose a person's identity to other parties - for example, when this is absolutely necessary to facilitate the effective investigation of a disclosure, provide procedural fairness, protect a person who has made a disclosure or make a public report on how a disclosure was dealt with.

\section{Protection of person making a disclosure}

A person who has made a disclosure to which the legislation applies should be protected against criminal or civil liability, or other detriment, for making the disclosure. For example, the person:

- should not be liable to prosecution for breach of a statutory secrecy provision

- should not incur civil liability, for example, for defamation or breach of confidence

- should not be subject to discipline or other workplace sanction, such as reduction in salary or position or termination of employment

- should be entitled to legal redress if they suffer detriment as a result of making the disclosure. 


\section{Disclosure outside an agency}

A disclosure made to a person or body that is not designated by the legislation to receive disclosures (for example, the media) should be protected in exceptional circumstances as defined in the legislation. The protection should apply only if it is reasonable in all the circumstances for the disclosure to be made to some other person or body to ensure that it is effectively investigated. As a general guide, the protection should apply when a person has first made the disclosure to a designated person or body and there has been a failure by that person or body to take reasonable and timely action.

\section{Agency responsibility to ensure protection}

The responsibilities of an agency under the legislation should include:

- $\quad$ establishing proper internal procedures in the agency for receiving, recording and investigating disclosures, for protecting people who make disclosures and for safeguarding the privacy of those who make disclosures

- ensuring that staff of the agency are made aware of their responsibilities under the legislation, including the responsibility to support and protect any person making a disclosure

- on receipt of a disclosure, assessing whether the person who made the disclosure - or any other person - faces any risk of detriment or requires special protection as a result

- where necessary, taking all reasonable measures to protect a person who has made a disclosure against direct or indirect detriment, actual or foreseeable

- taking remedial action in the event that a person suffers detriment as a result of making a disclosure.

It should be the duty of the senior executives of an agency to ensure that these responsibilities are met by the agency.

\section{Remedial action}

When a person suffers detriment as a result of a disclosure having been made, remedial action of the following kind should be taken by the agency or, failing that, the oversight agency, to the extent necessary to prevent or remedy the detriment:

- stopping the detrimental action and preventing its recurrence, including by way of injunction

- placing the person in the situation they would have been in but for the detrimental action, including if necessary the transfer of the person (with their informed consent) to another equivalent position

- an apology 
- compensation (pecuniary and/or non-pecuniary) for the detriment suffered, if the detriment could have been prevented, avoided or minimised

- disciplinary or criminal action against any person responsible for the detriment.

Jurisdiction to deal with compensation applications should be conferred on a low-cost tribunal with expertise in determining the rights and responsibilities of employers and employees. Consideration should also be given to reducing or reversing the onus of proof in cases of detrimental action, so that where a public interest disclosure has been made and detriment is suffered, it falls to those allegedly responsible to explain why the detriment did not result from the making of the disclosure.

\section{Continuing assessment and protection}

To the extent practicable, an assessment should be undertaken into the impact on a person of having made a disclosure under the legislation. This assessment should be undertaken at an appropriate time or times (for example, at intervals of two, five or 10 years). This assessment can be conducted by the agency to which the disclosure was made or by the oversight agency.

\section{Discussion and conclusions}

This chapter has presented 13 key principles for the design or review of public interest disclosure legislation in the public sector. While there could be different options for implementing these principles, no legislation can be considered to be adequately comprehensive unless all these issues are addressed. Fortunately, the research in this book is already showing that if this occurs, the results are likely to be positive.

The reform of existing whistleblowing legislation is already an important issue for many Australian governments. In particular, the Commonwealth Government - for whom the existing legislative framework is weakest-has committed to substantial reform by introducing best-practice legislation. Previous analysis has shown that best practice does not lie in any existing law, but requires something of a 'second-generation' approach, including reconsideration of many of the fundamental principles rather than ad hoc tinkering with existing laws. The principles set out in this chapter are intended to provide a basic guide for this second-generation approach. In the interests of the increasing number of public officials who transfer between different governments within the Australian public sector, there are benefits to be gained from uniform public interest disclosure legislation if a new best-practice approach emerges.

The present research has also demonstrated that while current best practice can be found on different issues in different existing laws, there are major deficiencies that all legislative approaches to date tend to share. This chapter has focused on 
several of these issues - in particular, operational systems, compensation avenues and protection of public whistleblowing. The extent of the problems confirms there is presently a divide between the important intentions or 'symbolism' of these frameworks and their substantive effectiveness. The symbolism of whistleblower protection is a powerful force, frequently reaffirmed at the highest levels of government. Until legislative frameworks more effectively fulfil these practical needs, however, the full benefits will not be achieved. Fortunately, it is now increasingly clear that reform is not only needed, but possible.

\section{ENDNOTES}

1 Wheadon v. State of New South Wales, unreported, District Court of New South Wales, No. 7322 of 1998 (2 February 2001) per Cooper J.; see NSW Ombudsman (2004, 2005).

2 Howard v. State of Queensland, [2000] QCA 223 (9 June 2000), per Thomas, JA (with whom the rest of the court agreed).

3 Reeves-Board v. Queensland University of Technology, [2001] QSC 314 (28 August 2001), [2002] 2 Qd R 85, per Mullins J.

4 Owens v. University of Melbourne \& Anor, [2008] VSC 174 (27 May 2008), per Judd J.

5 Ibid.

${ }^{6}$ Fraser v. Public Service Staff Relations Board, [1985] 2 SCR 455 at 470, per Dickson CJ (Supreme Court of Canada), cited in, for example, Alberta Union of Provincial Employees v. Alberta, 2000 ABQB 600; see Carson (2006); Brown and Latimer (forthcoming).

7 Bennett v. President, Human Rights and Equal Opportunity Commission, (2003) 204 ALR 119, per Finn J. The case concerned the validity of Public Service Regulation 7(13), prohibiting an Australian Public Service employee from disclosing 'directly or indirectly, to any person any information about public business or anything of which the employee has official knowledge'.

8 Employment Rights Act 1996 (UK), s 43G and 43H, as inserted by Public Interest Disclosure Act 1998 (UK); see explanatory guide by Public Concern at Work, <www.pcaw.co.uk> 